\title{
Perceived confidence to use female condoms among students in Tertiary Institutions of a Metropolitan City, Southwestern, Nigeria
}

\author{
Taiwo A. Obembe ${ }^{1,2^{*}} \mathbb{0}$, Ayo S. Adebowale ${ }^{3}$ and Kehinde O. Odebunmi ${ }^{4}$
}

\begin{abstract}
Background: Latex condoms for men have been documented to offer high efficacy as both a contraceptive and protection against sexually transmitted diseases. This equally establishes the importance of continued research on female condoms. This study aims to investigate the perceived confidence to use the female condoms amongst undergraduate female students from selected tertiary institutions from Ibadan Southwestern Nigeria.
\end{abstract}

Methods: The study was a descriptive cross-sectional survey involving 388 female undergraduate students selected through a multistage sampling technique. The survey was carried using pre-tested semi-structured questionnaires. Quantitative data were analyzed using the Statistical Package for the Social Sciences to generate frequencies, cross tabulations of variables at $5 \%$ level of significance.

Results: Mean age of respondents $18.26 \pm 3.45$ with most students being $20-24$ years (55.2\%), single (92.8\%), Yorubas (85.6\%) and from the polytechnic institutions (41.0\%). Only $10.8 \%$ had good perceived confidence to use a female condom. Perceived confidence was significantly higher amongst other ethnicities (19.59 \pm 3.827$)$ compared to Yoruba ethnicity $(18.04 \pm 3.337)(F=9.935 ; p<0.05)$. Likewise, students from the Polytechnic campuses exhibited significantly higher mean scores $(18.81 \pm 3.187)$ compared to others $(F=3.724 ; p<0.05)$. Perception towards the condom was a significant factor that influenced the confidence to use a female condom ( $F=9.896 ; p<0.000$ ).

Conclusions: Concerted efforts are advocated to improve the low perception exhibited towards the use of female condoms and the low perceived confidence to its utilization. This would help to transfer the decision making and control to women thus contributing to their empowerment and increased protection from unplanned pregnancies and sexually transmitted diseases.

Keywords: Female condom, Barrier methods, Perceived confidence, Tertiary students, Undergraduates

\section{Background}

The female condom first proposed by Lasse Hessel in mid-80s [1], is certified to guard against unwanted pregnancies and sexually transmitted diseases during vaginal intercourse [2, 3]. It's distribution and availability

\footnotetext{
*Correspondence: tobembe@cartafrica.org

${ }^{1}$ Department of Health Policy \& Management, Faculty of Public Health,

College of Medicine, University of Ibadan, Ibadan, Nigeria

Full list of author information is available at the end of the article
}

worldwide has doubled from 25 million to 50 million and 60 million units in 2007, 2010 and 2012 respectively [4, 5].

Due to young women's increased susceptibility to HIV and other sexually transmitted infections particularly prevailing gender norms that endorse male dominance in decision making with respect to sexual issues [6], it would be easily assumed that availability, uptake, and utilization of female condoms would be optimal. HIV-related infections account for most deaths among women between 15 and 49 years with close to $60 \%$ of the total global 
population of people living with HIV-infected women in sub-Saharan Africa [7] with gender inequality as a driving force of the epidemic [8]. In Nigeria, the prevalence of sexually transmitted diseases among Nigeria female youths is as high as 17\% [9]. About 2.9 million people live with HIV/AIDs with a concurrent startling low rate of male condom use estimated at 25 and $11 \%$ for sexually active males and females respectively [10, 11]. Furthermore, about 8 out of every 10 infected women with HIV by having unprotected sex with an infected male partner. This is particularly important as women's biological vulnerability to HIV through sexual intercourse is up to four times as high compared to the men. Yet, the subordinate disposition of women often offers very little control over whether a man uses a condom or not $[1,3]$.

The general uptake and utilization of the female condom remain inadequate with both men and women having mixed reactions about its use. For example, Malawian women hold a negative attitude towards its use [12]. Surveyed women attributed their main discouragement of use to fears of negative consequence, poor knowledge, non-user friendly and reduction in sexual pleasure [12-14]. In another study conducted in South Africa, main facilitators for usage and acceptance of female condom by men included the convenience of use, curiosity and enhanced sexual sensation while barriers ranged from insertion difficulties, concerns over loss of control and limited familiarity largely ranging from socioeconomic to environmental factors $[6,15]$. Despite the extensive literature on barriers and facilitators of condom use amongst both males and females, studies have not taken into cognizance the understanding of individual differences with regards to adoption and utilization of female condom as a health behavior [16]. The theory of reasoned action (with emphasis on self-efficacy) "relies on individual-focused cognitive models of rational decision making, which are explicitly abstracted from social context, to explain health-related behavior" [17]. Selfefficacy that refers to an individual's perception of his or her competence to successfully perform a behavior [18], is a cogent factor requiring in-depth investigation when examining the sub-optimal uptake of promising health interventions such as the utilization of female condoms amongst women. Our study thus sought to examine the factors that influence the perceived confidence to use the female condom amongst the female undergraduate students from selected tertiary institutions in Southwestern Nigeria.

\section{Methods}

The study employed a cross-sectional study design to measure perceived confidence to use a female condom during sexual encounters and its associated factors among undergraduate female students from selected tertiary institutions in Oyo State.

The study was conducted across selected tertiary institutions across Ibadan metropolis of Oyo State, Nigeria. Data were collected using a 57-item interviewer-administered questionnaire that consisted of demographic characteristics, sexual activity, transactional sex, awareness of female condom, perception (attitude) towards the female condom, perceived confidence (self-efficacy) to use the female condom and utilization of female condoms. Validity was first ensured by developing the questionnaire after a review of the literature prepared in English. It was then translated into Yoruba and back-translated to verify that the original meaning was not lost. We utilised four types of questions; binary questions (such as yes/no); multiple choice questions (in which the options were mutually exclusive and covered all possible answers); specific questions that do not specify options (for example how old are you?); and scaling questions (Likert scale was used to assess students perceived level of self-efficacy) [19]. The Flesch reading ease score 64.3 and the Coleman-Liau index of 8 (indicating that it was fairly easy to read) were used to ensure proper comprehension of our instrument $[20,21]$. A pre-test of the questionnaire was carried out in $10 \%$ of the sample size in similar tertiary institutions (a university, polytechnic and a college of education) from a neighboring state, Osun State among 40 students before the actual data collection. Reliability testing of the scales yielded an overall Cronbach's Alpha of 0.847 (95\% CI 0.824-0.868). The self-efficacy scale that was used was adapted from technical, assertiveness, and sexual control components of 'condom use self-efficacy scale' proposed by Baele et al. [22] and condom use self-efficacy (CUSESE) [23].

A minimum sample size of 259 was obtained using a 5\% level of significance, at a $90 \%$ power and a $5 \%$ tolerable error. The prevalence of positive attitudes towards the use of a female condom (46\%) amongst female undergraduate students was used as our reference value [24]. This was increased to 323 to adjust for a $20 \%$ non-response.

A multistage sampling technique was employed for recruitment of study participants. First, tertiary institutions in the state were divided into three strata: universities, polytechnics, and colleges of education. One institution was randomly selected from each stratum (total 3). In each selected institution, two female halls of residence were randomly selected (total 6). A full list of registered students from all selected halls of residence was obtained followed by a systematic random selection of 65 students per hall of residence. The rooms were systematically selected using the equiprobability method [25]. The 1st room was picked randomly between the rooms 1-3 of each hall after which the sampling interval 
was estimated by dividing the total number of rooms in the hall (population size) by 65 (sample size). This sampling interval was thereafter used to determine the rooms to be skipped or picked. In every room that was picked, only 1 student was randomly selected per room to be interviewed. This was done by asking all students to pick numbers randomly from a bag intermingled with a blank sheet; the student that picked a blank sheet was selected to participate in each room. All visitors, unlawful residents, and students that were not registered in the halls of residence were considered ineligible to be part of our study. This was verified by sighting both the identification cards issued by the institution and also by the hall of residence. Other eligibility criteria considered were consent of respondents to participate in the study and availability as at the time of the data collection. A total of $400 \mathrm{stu}-$ dents were surveyed, however 12 entries were dropped at analysis due to improperly filled survey instruments. The questionnaire was designed to be self-completed.

Our independent variables included the age, marital status, religion, ethnicity, type of institution, family setting, and perception towards the female condom while the dependent variable is the "perceived confidence to use a female condom". Perception towards the use of female condom and perceived confidence to use the female condom were assessed by 7 -item and 11-item constructs respectively. Strongly agree, agree, indifferent, disagree and strongly disagree were scored 1, 2, 3, 4, 5 accordingly. Maximum obtainable scores (by summing up all items) for perception towards the female condom and perceived confidence to use the female condom are 30 and 55 respectively. Scores of $\geq 23,15-22$, and $\leq 14$ for perception towards the female condom were re-categorized as good, fair and poor perception while scores of $\geq 42,28-41$, and $\leq 28$ for perceived confidence were categorized as good, fair and poor. Associations between the dependent variable (mean scores of perceived confidence to use a female condom) and the independent variables were investigated using $\mathrm{F}$ test at 5\% level of significance. Associations between the dependent variable (categorized perceived confidence to use a female condom) and the independent variables were investigated using Chi square test at $5 \%$ level of significance. Frequency tables were generated for relevant variables while descriptive statistics were used to summarize continuous variables (such as means and standard deviations).

Approval for the conduct of the study was obtained from the Ethics Review Committee of Oyo state Ministry of Health. Written informed consent was also obtained from the students' prior to questionnaire administration and respondents' anonymity was protected by ensuring that no individual identifiers existed in the instruments or in the electronic data set. Parental consent was also sought and obtained for participants younger than 16 years.

\section{Results}

The ages of the respondents ranged from 14 to 36 years with a mean of $18.26 \pm 3.45$ years. More than half (55.2\%) of our respondents were aged 20-24 years. Expectedly, the majority of our respondents were never married (92.8\%), Christians (72.9\%), from monogamous family settings (72.2\%) and of Yoruba descent (85.6\%) (Table 1). Students from Polytechnic institutions (41.0\%) accounted for a greater proportion of our study participants followed closely by those from the universities (35.6\%). Most students were in the 2nd year (36.9\%) trailed closely by those in the 3rd year (25.5\%). Students in the first year and 4 years and above were 20.6 and $17.0 \%$ respectively (Table 1).

Most respondents demonstrated fair perception (76.5\%) towards using the female condom while those that had good and poor perception were 10.8 and $12.6 \%$ respectively (Fig. 1).

\section{Table 1 Sociodemographic characteristics of respondents} $(\mathrm{n}=388)$

\begin{tabular}{|c|c|c|c|}
\hline S/no. & Variable & Frequency (n) & Percentage (\%) \\
\hline \multirow[t]{4}{*}{1.} & Age & & \\
\hline & $14-19$ & 104 & 26.8 \\
\hline & $20-24$ & 214 & 55.2 \\
\hline & $25+$ & 70 & 18.0 \\
\hline \multirow[t]{3}{*}{2.} & Marital status & & \\
\hline & Never married & 360 & 92.8 \\
\hline & Ever married/cohabiting & 28 & 7.2 \\
\hline \multirow[t]{3}{*}{3.} & Religion & & \\
\hline & Christianity & 283 & 72.9 \\
\hline & Islam & 105 & 27.1 \\
\hline \multirow[t]{3}{*}{4.} & Ethnicity & & \\
\hline & Yoruba & 332 & 85.6 \\
\hline & Others & 56 & 14.4 \\
\hline \multirow[t]{4}{*}{5.} & Type of institution & & \\
\hline & Polytechnic student & 159 & 41.0 \\
\hline & University student & 138 & 35.6 \\
\hline & $\begin{array}{l}\text { College of education } \\
\text { student }\end{array}$ & 91 & 23.5 \\
\hline \multirow[t]{5}{*}{6.} & Level of education & & \\
\hline & 1st year & 80 & 20.6 \\
\hline & 2nd year & 143 & 36.9 \\
\hline & 3rd year & 99 & 25.5 \\
\hline & 4th year and above & 66 & 17.0 \\
\hline \multirow[t]{3}{*}{7.} & Family setting & & \\
\hline & Monogamous & 280 & 72.2 \\
\hline & Polygamous & 108 & 27.8 \\
\hline
\end{tabular}




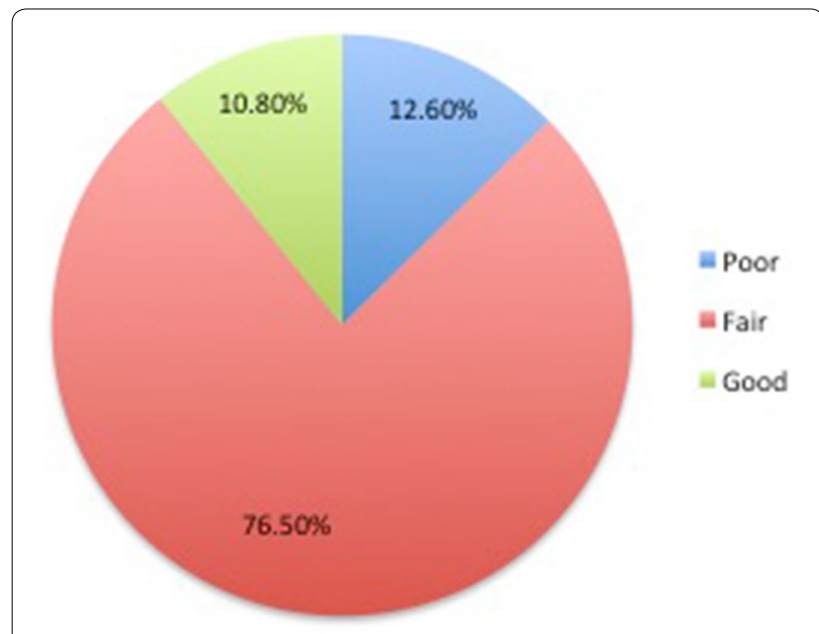

Fig. 1 Perceived confidence to use the female condom

Less than half of our participants (44.6\%) felt bold/confident enough to use a female condom before a sexual intercourse. Amongst these, only $14.7 \%$ of these felt strongly of their abilities to use a female condom if the situation arose. About one-third (35.1\%) attested that persuading their partners to accept the utilization of a female condom will be difficult based on health (STI/HIV) reasons while $43.6 \%$ participants disagree with the perception. Likewise, 39.7\% of participants wouldn't feel comfortable using female condom based on suspicions of infidelity while $41.7 \%$ disagreed with the idea. Some respondents also agreed that they would not be able to convince their partners to support the use of the female condom due to anger issues (38.1\%). Others (42.5\%) disagreed that temper and anger issues would not deter them from suggesting it to their partners. Only $31.4 \%$ could stop to insert a female condom during a sexual intercourse. Less than half of respondents (45.1\%) believed that they can suggest and convince an unwilling partner to agreeing to accept the idea of a female condom (Table 2).

Perceived confidence as exhibited by teenagers 14-19 years $(18.37 \pm 3.484)$ and young adults 20 -24 years $(18.37 \pm 3.430)$ were higher than those above 25 years $(17.76 \pm 3.466)$ of age though not significant $(\mathrm{F}=0.908 ; \mathrm{p}=0.404)$. Participants that were never married $(18.30 \pm 3.422)$ also were perceived to be more confident compared to those that were "ever married" $(17.75 \pm 3.826)$ also not a significant finding $(\mathrm{F}=0.660$; $\mathrm{p}=0.417$ ) (Table 3). Mean scores for perceived confidence amongst Christians $(18.34 \pm 3.484)$ was marginally higher than the combined scores from Muslims $(18.04 \pm 3.362)(\mathrm{F}=0.597 ; \mathrm{p}=0.440)$. Perceived confidence was significantly higher amongst other ethnicities (19.59 \pm 3.827$)$ compared to Yoruba ethnicity $(18.04 \pm 3.337)(\mathrm{F}=9.935 ; \mathrm{p}=0.02)$. Likewise, significant differences in mean scores were observed amongst the students based on the type of institution in which they were schooling. Students from the Polytechnic campuses exhibited higher scores $(18.81 \pm 3.187)$ compared to University students $(18.03 \pm 3.683)$ and students from college of education (17.66 \pm 3.426$)$ $(\mathrm{F}=3.724 ; \mathrm{p}=0.025)$ (Table 3$)$. The mean scores for perceived confidence amongst students from the second year $(18.57 \pm 3.528)$ were higher than those of 1 st year $(18.50 \pm 3.265)$, 4th-year students $(18.15 \pm 3.592)$ and those from the 3 rd year $(17.70 \pm 3.364)(\mathrm{F}=1.410$; $\mathrm{p}=0.239$ ). Type of family setting from which the participants hailed from also showed an impact on perceived confidence though not significant. Those from monogamous family settings were seen to possess higher confidence scores $(18.34 \pm 3.454)$ compared to their counterparts from polygamous family settings $(18.06 \pm 3.449)(\mathrm{F}=0.480 ; \mathrm{p}=0.489)$. Perception towards the female condom had a very significant

Table 2 Reasons influencing use of female condom (FC)

\begin{tabular}{|c|c|c|c|c|c|}
\hline & N (\%) & N (\%) & N (\%) & N (\%) & N (\%) \\
\hline & $\begin{array}{l}\text { Strongly } \\
\text { agree }\end{array}$ & Agree & Indifferent & Disagree & $\begin{array}{l}\text { Strongly } \\
\text { disagree }\end{array}$ \\
\hline $\begin{array}{l}\text { 1. If given the female condom, I will be bold/confidence enough } \\
\text { to use it before intercourse }\end{array}$ & $57(14.7 \%)$ & 116 (29.9\%) & 77 (19.8\%) & $92(23.7 \%)$ & $46(11.9 \%)$ \\
\hline $\begin{array}{l}\text { 2. I don't think I can persuade my partner to accept the use of the } \\
\text { female condom because he may feel I think he has an STI/HIV }\end{array}$ & $53(13.7 \%)$ & $83(21.4 \%)$ & $83(21.4 \%)$ & 105 (27.1\%) & $64(16.5 \%)$ \\
\hline $\begin{array}{l}\text { 3. I wouldn't feel comfortable using female condom because my } \\
\text { partner may think It's because I suspect him of infidelity }\end{array}$ & $63(16.2 \%)$ & $91(23.5 \%)$ & 72 (18.6\%) & 118 (30.4\%) & $44(11.3 \%)$ \\
\hline $\begin{array}{l}\text { 4. I wouldn't feel comfortable using female condom because of } \\
\text { fear that my partner may get furious or lose his temper }\end{array}$ & $42(10.8 \%)$ & 106 (27.3\%) & 75 (19.3\%) & 109 (28.1\%) & $56(14.4 \%)$ \\
\hline 5. I can stop to insert a female condom during the act & $51(13.1 \%)$ & $71(18.3 \%)$ & $94(24.2 \%)$ & $116(29.9 \%)$ & $56(14.4 \%)$ \\
\hline $\begin{array}{l}\text { 6. I can suggest and initiate use of female condom to an unwilling } \\
\text { partner }\end{array}$ & $67(17.3 \%)$ & $108(27.8 \%)$ & $80(20.6 \%)$ & $70(18.0 \%)$ & $63(16.2 \%)$ \\
\hline
\end{tabular}


Table 3 Association between sociodemographic variables and mean scores for perceived confidence to use the female condom

\begin{tabular}{|c|c|c|c|c|c|}
\hline & & $\begin{array}{l}\text { Perceived con } \\
\text { condom }\end{array}$ & fidence to use & a femal & \\
\hline & & Mean (SD) & Mean square & $\mathbf{F}$ & $\mathrm{p}$ \\
\hline 1. & Age & & & & \\
\hline & 14-19 & $18.37 \pm 3.484$ & 10.814 & 0.908 & 0.404 \\
\hline & $20-24$ & $18.37 \pm 3.430$ & & & \\
\hline & $25+$ & $17.76 \pm 3.466$ & & & \\
\hline 2. & Marital status & & & & \\
\hline & Never married & $18.30 \pm 3.422$ & 7.859 & 0.660 & 0.417 \\
\hline & Ever married & $17.75 \pm 3.826$ & & & \\
\hline 3. & Religion & & & & \\
\hline & Christianity & $18.34 \pm 3.484$ & 7.108 & 0.597 & 0.440 \\
\hline & Islam & $18.04 \pm 3.362$ & & & \\
\hline 4. & Ethnicity & & & & \\
\hline & Yoruba & $18.04 \pm 3.337$ & 115.589 & 9.935 & $0.002^{*}$ \\
\hline & Others & $19.59 \pm 3.827$ & & & \\
\hline 5. & Type of institution & & & & \\
\hline & $\begin{array}{l}\text { Polytechnic } \\
\text { student }\end{array}$ & $18.81 \pm 3.187$ & 43.715 & 3.724 & $0.025^{*}$ \\
\hline & $\begin{array}{l}\text { University } \\
\text { student }\end{array}$ & $18.03 \pm 3.683$ & & & \\
\hline & $\begin{array}{l}\text { College of } \\
\text { education }\end{array}$ & $17.66 \pm 3.426$ & & & \\
\hline 6. & Level of education & & & & \\
\hline & First year & $18.50 \pm 3.265$ & 16.732 & 1.410 & 0.239 \\
\hline & Second year & $18.57 \pm 3.528$ & & & \\
\hline & Third year & $17.70 \pm 3.364$ & & & \\
\hline & Fourth year & $18.15 \pm 3.592$ & & & \\
\hline 7. & Family setting & & & & \\
\hline & Monogamous & $18.34 \pm 3.454$ & 5.720 & 0.480 & 0.489 \\
\hline & Polygamous & $18.06 \pm 3.449$ & & & \\
\hline 8. & Perception towards & female condom & & & \\
\hline & Poor & $16.87 \pm 3.061$ & 112.623 & 9.896 & $0.000^{*}$ \\
\hline & Fair & $18.66 \pm 3.519$ & & & \\
\hline & Good & $18.75 \pm 3.237$ & & & \\
\hline
\end{tabular}

* Significant associations

association with how students perceived their confidence to use the female condom when the situation demanded it. Mean scores for students with good perception $(18.75 \pm 3.237)$ were significantly higher than those with fair perception $(18.66 \pm 3.519)$ and poor perception $(16.87 \pm 3.061)$ respectively $(\mathrm{F}=9.896$; $\mathrm{p}<0.000$ ) (Table 3).

With respect to age groups with good perceived confidence, more young adults (20-24 years) had good perceived confidence to use the female condom (52.4\%) compared to the teenagers $14-19$ years $(28.6 \%)$ and those
$25+$ years $(19.0 \%)$ respectively $\left(\mathrm{X}^{2}=4.588, \mathrm{p}=0.332\right)$ (Table 4). More participants that were never married had good perceived confidence (92.8\%) when compared to those ever married/cohabiting (7.2\%) $\left(\mathrm{X}^{2}=4.250\right.$; $\mathrm{p}=0.119)$. More Christians (73.8\%) compared to Muslims $(26.2 \%)$ had good perceived confidence in using the female condom $\left(X^{2}=0.361 ; p=0.835\right)$. Significantly more females of Yoruba ethnicity $(71.4 \%)$ had good perceived confidence to use a female condom compared to participants from other ethnicities $(28.6 \%)\left(\mathrm{X}^{2}=7.915\right.$; $\mathrm{p}=0.019$ ) (Table 4). Similarly, more polytechnic students (45.2\%) demonstrated good perceived confidence to use the female condom compared to the participants from the university $(40.5 \%)$ and those from the colleges of education (14.3\%); though not a significant association $\left(\mathrm{X}^{2}=6.484 ; \mathrm{p}=0.166\right)$ (Table 4$)$. More respondents in the 2nd year (45.2\%) had good perceived confidence to use the female condom compared to students in other levels though not a significant finding $\left(X^{2}=6.667\right.$; $\mathrm{p}=0.353)$. More students from monogamous family settings $(76.2 \%)$ had good perceived confidence compared to those from polygamous settings $(23.8 \%)\left(\mathrm{X}^{2}=1.533\right.$; $\mathrm{p}=0.465$ ) (Table 4). Significantly more respondents with fair perception (80.9\%) towards the female condom showed good perceived confidence with respect to other cadres $\left(\mathrm{X}^{2}=27.755 ; \mathrm{p}<0.000\right)($ Table 4$)$.

\section{Discussion}

It is not surprising that majority of our participants are between 14 and 24 years with a mean age that corresponds closely with school age in tertiary institutions in Nigeria [26]. The majority of our participants being single also corroborates the national estimates that put median age at first marriage for females at 18.1 years [27]. Similarly, findings such as the preponderance of respondents being Yorubas and Christians also can be explained logically by the fact that the study was carried out in the capital city of Oyo State inhabited predominantly by such [28].

The desire for lifetime partners or "true love" amongst older participants may well explain the lower perceived confidence to negotiate with partners on sexual matters [29]. Lack of trust, loss of control, the likelihood of domestic violence, infidelity were highlighted as issues raised by our respondents that would reduce their perceived confidence in the event of unplanned sexual encounters ratifies what is documented in other studies $[14,30,31]$.

Only $35.1 \%$ of our respondents can negotiate with sexual partners on the need and importance of a female condom for sexual activities which is in contrast to findings of another study where about $73.0 \%$ of female undergraduates had been engaged in sexual negotiations 
Table 4 Correlates between socio-demographic variables and perceived confidence to use the female condom

\begin{tabular}{|c|c|c|c|c|c|c|}
\hline & & \multicolumn{5}{|c|}{ Perceived confidence to use female condom } \\
\hline & & Poor & Fair & Good & $x^{2}$ & $p$ \\
\hline \multirow[t]{4}{*}{1.} & Age (years) & & & & & \\
\hline & $14-19$ & $12(24.5 \%)$ & $80(26.9 \%)$ & $12(28.6 \%)$ & 4.588 & 0.332 \\
\hline & $20-24$ & $23(46.9 \%)$ & $169(56.9 \%)$ & $22(52.4 \%)$ & & \\
\hline & $25+$ & $14(28.6 \%)$ & $48(16.2 \%)$ & $8(19.0 \%)$ & & \\
\hline \multirow[t]{3}{*}{2.} & Marital status & & & & & \\
\hline & Never married & $42(85.7 \%)$ & $279(93.9 \%)$ & $39(92.8 \%)$ & 4.250 & 0.119 \\
\hline & Ever married/cohabiting & $7(14.3 \%)$ & $18(6.1 \%)$ & $3(7.2 \%)$ & & \\
\hline \multirow[t]{3}{*}{3.} & Religion & & & & & \\
\hline & Christianity & $34(69.4 \%)$ & $218(73.4 \%)$ & $31(73.8 \%)$ & 0.361 & 0.835 \\
\hline & Islam & $15(30.6 \%)$ & $79(26.6 \%)$ & $11(26.2 \%)$ & & \\
\hline \multirow[t]{3}{*}{4.} & Ethnicity & & & & & \\
\hline & Yoruba & $44(89.8 \%)$ & $258(86.9 \%)$ & $30(71.4 \%)$ & 7.915 & $0.019^{*}$ \\
\hline & Others & $5(10.2 \%)$ & $39(13.1 \%)$ & $12(28.6 \%)$ & & \\
\hline \multirow[t]{4}{*}{5.} & Type of institution & & & & & \\
\hline & Polytechnic student & $14(28.6 \%)$ & $126(42.4 \%)$ & $19(45.2 \%)$ & 6.484 & 0.166 \\
\hline & University student & $23(46.9 \%)$ & $98(33.0 \%)$ & $17(40.5)$ & & \\
\hline & College of education student & $12(24.5 \%)$ & $73(24.6 \%)$ & $6(14.3 \%)$ & & \\
\hline \multirow[t]{5}{*}{6.} & Level of education & & & & & \\
\hline & First year & $7(14.3 \%)$ & $64(21.5 \%)$ & $9(21.4 \%)$ & 6.667 & 0.353 \\
\hline & Second year & $15(30.6 \%)$ & $109(36.7 \%)$ & $19(45.2 \%)$ & & \\
\hline & Third year & $17(34.7 \%)$ & $76(25.6 \%)$ & $6(14.3 \%)$ & & \\
\hline & Fourth year and above & $10(20.4 \%)$ & $48(16.2 \%)$ & $8(19.1 \%)$ & & \\
\hline \multirow[t]{3}{*}{7.} & Family setting & & & & & \\
\hline & Monogamous & $32(65.3 \%)$ & $216(72.7 \%)$ & $32(76.2 \%)$ & 1.533 & 0.465 \\
\hline & Polygamous & $17(34.7 \%)$ & $81(27.3 \%)$ & $10(23.8 \%)$ & & \\
\hline \multirow[t]{4}{*}{8.} & Perception towards female condom & & & & & \\
\hline & Poor & $24(49.0 \%)$ & 62 (20.9\%) & 3 (7.1\%) & 27.755 & $0.000^{*}$ \\
\hline & Fair & $19(38.8 \%)$ & $182(61.3 \%)$ & 34 (80.9\%) & & \\
\hline & Good & $6(12.2 \%)$ & 53 (17.8\%) & 5 (12.0\%) & & \\
\hline
\end{tabular}

* Significant associations

before [32]. Adebiyi and Asuzu argue that such circumstances that hinder condom use are mostly fostered within relationships where the opportunity for discussion on sexual matters is non-existent [13] and advocates for a need to conduct more studies that focus on communication within sexual partnerships. The increased perceived confidence by other ethnicities to use the female condom relatively to Yoruba contradicts the literature [33]. Though this contradiction may be because our study focused on women alone as opposed to maleonly respondents that Ankomah and colleagues surveyed [33]. Also contrary to our findings, Ayoola et al. found southeastern women to possess a reduced capacity to negotiate condom use with their partners [34]. Studies that probe for reasons why other ethnicities have higher perceived confidence to Yorubas are highly desirable considering the relative literacy of the Yorubas compared to other ethnicities [27]. Likewise, the exhibition of significantly higher mean scores amongst polytechnic students compared to other institutions calls for deeper studies. Lax family ties that are commoner with polygamous family settings $[35,36]$ can explain why mean scores for perceived confidence of respondents from monogamous family settings were higher than those from polygamous family settings.

Even though our study primarily surveyed individual level factors as opposed to socio-economic and environmental factors influencing condom use, poor perception towards female condom use still supports findings from literature in which perceptions that influenced the use of condoms were varied [15]. This finding is also mirrored in health settings where providers in South Africa were 
less likely to counsel women on female condoms but were more likely to counsel women on male condoms [37]. The low perceived confidence to use the female condom may translate well to the poor utilization of the female condom which is reiterated in other studies [14, 27]. Apart from logistics which considerably impedes the rate of availability of female condoms $[37,38]$, other factors may well be responsible for this poor utilization such as difficulties with insertion [39].

As with cross-sectional surveys, our study can elucidate factors associated with the use of the female condom, but it cannot establish causation. Our study failed to examine the relationship between some important variables such as socio-economic status on perceived confidence to use the female condom among the undergraduate students. It will be desirable to explore such relationships in further studies. Our study could have yielded more robust findings if a supportive qualitative study had been carried out to probe the reasons for the different levels of the perceived confidence to use the female condom across the different tertiary institutions. Qualitative studies and triangulation of findings should be undertaken in subsequent studies in order to establish a deeper understanding of the factors influencing such variations in outcome of interest. The generalizability of our results is limited due to the factors chosen for our analysis. In addition, this study did not consider service related issues [40] that contribute to the perceived confidence in its usage.

\section{Policy issues}

Considering the grossly unmet need for contraception, coupled with the absence of female-led and female-initiated alternatives to the female condom, stronger policies are required to explore the advantages of female condom towards reducing the scourge of HIV/AIDs and sexually transmitted diseases in sub-Saharan Africa [41]. Female condoms, not only help to transfer control to women in sexual encounters but also assists the 5th goal in the sustainable development goals which aims to empower women [42].

Studies have reiterated that the concurrent availability of female condoms results in higher rates of protected sex, greater negotiating power and control of their health compared with only-male condom availability and the affordability [5]. This availability will be greatly enhanced if policies that promote subsidization of costs (for developing countries in sub-Saharan Africa where there are high prevalent rates of HIV infection) or that advocate free female condoms are embraced $[3,43]$.

The promise of an increased acceptance and uptake of the female condom when basic barriers are removed is certain, particularly when free trial samples are integrated into standard clinical practice and public health programs [44]. Ensuring dual availability of both types of condoms not only offers more protection but also improves the cost-effectiveness for preventing new HIV and sexually transmitted infections.

However, despite all these initiatives, the Federal Government of Nigeria has not taken any major leap towards increasing the availability of female condoms or its subsidization. Even though policy makers realize the need for revision and re-positioning of the National Health Policy to attain Sustainable Development Goals [45, 46], there is very little documentation or plan for scale up of availability of the female condom in the Nigerian Country Cooperation Strategic policy document that was eventually developed [47].

At the global level, more advocacy is also urgently required to reorient AIDS policy actors from viewing the AIDS scourge in the context of gender and reproductive health instead of sexuality and sexual rights [8]. Lastly, female-initiated barrier alternatives such as vaginal microbes and diaphragms that are non-toxic and sexual health services that are integrated into maternal health care and reproductive services are added initiatives [48] that can be explored at the global and national forums.

\section{Conclusions}

The female condom offers better promises in the fight against HIV/AIDs and STD in Nigeria and greater subSaharan Africa if the availability of the female condom is buffered up and awareness campaigns to promote the populace on the benefits are scaled up. Sustained political will to subsidize costs of female condoms is equally needed to protect against risky sexual behaviors that are not uncommon occurrences with undergraduates of tertiary institutions.

\section{Abbreviations \\ FC: female condom; HMO: Health Maintenance Organization; HIV: human immunodeficiency syndrome; STD: sexually transmitted diseases; STI: sexually transmitted infections.}

\section{Authors' contributions}

TA conceptualized the study, wrote out the protocol and conducted the literature review. KO supervised the field data collection and data entry. AS conducted the data analysis. TO wrote the first draft of the manuscript. All authors read and approved the final manuscript.

\section{Author details}

${ }^{1}$ Department of Health Policy \& Management, Faculty of Public Health, College of Medicine, University of Ibadan, Ibadan, Nigeria. ${ }^{2}$ Faculty of Health Sciences, University of Witwatersrand, Johannesburg, South Africa. ${ }^{3}$ Department of Epidemiology and Medical Statistics, Faculty of Public Health, College of Medicine, University of Ibadan, Ibadan, Nigeria. ${ }^{4}$ Department of Hospice and Palliative Medicine, University College Hospital, Ibadan, Nigeria.

\section{Acknowledgements}

The authors would like to thank all the students of the selected schools for granting the audience and the permission to be interviewed. The authors 
also appreciate the assistance of Professor Ademola Ajuwon-Department of Health Promotion and Education, University of Ibadan for his thorough review of the manuscript.

\section{Competing interests}

The authors declare that they have no competing interests.

\section{Availability of data and materials}

The dataset generated and/or analyzed for this study is available in Figshare public repository with Accession Number 4491650 (https://doi.org/10.6084/ m9.figshare.4491650.v1) [49].

\section{Consent for publication}

Not applicable.

\section{Ethics approval and consent to participate}

Ethical approval for the conduct of the study was obtained from the Department of Planning Research and Statistics, Ministry of Health, Oyo State Secretariat, Ibadan, Nigeria. Data collection process was performed according to standard ethical guidelines. Consent was also obtained from respective hall wardens of selected halls of residence. Both written and oral consents were also obtained from the students' prior to questionnaire administration and respondents' anonymity was protected by ensuring that no individual identifiers existed in the instrument or in the electronic data set. Parental consent was also sought and obtained for participants younger than 16 years.

\section{Funding}

The authors appreciate the funding support from Premier Medicaid International HMO, Nigeria for the execution of this study. This research was also partially supported by the Consortium for Advanced Research Training in Africa (CARTA). CARTA is jointly led by the African Population and Health Research Center and the University of the Witwatersrand and funded by the Wellcome Trust (UK) (Grant No: 087547/Z/08/Z), the Department for International Development (DfID) under the Development Partnerships in Higher Education (DelPHE), the Carnegie Corporation of New York (Grant No: B 8606), the Ford Foundation (Grant No: 1100-0399), Google.Org (Grant No: 191994), SIDA (Grant No: 54100029) and MacArthur Foundation (Grant No: 10-95915-000-INP).

\section{Publisher's Note}

Springer Nature remains neutral with regard to jurisdictional claims in published maps and institutional affiliations.

Received: 26 January 2017 Accepted: 3 August 2017 Published online: 11 August 2017

\section{References}

1. Kerrigan D. The female condom and AIDS. UNAIDS Point of View. 1997.

2. Rodriguez K, Ventura-DiPersia C, LeVasseur MT, Kelvin EA. Inconsistencies on US departments of health websites regarding anal use of the female condom. AIDS Behav. 2015;19(7):1141-9.

3. Deniaud F. Current status of the female condom in Africa. Sante. 1997;7(6):405-15.

4. Beksinska ME, Piaggio G, Smit JA, Wu J, Zhang Y, Pienaar J, et al. Performance and safety of the second-generation female condom (FC2) versus the woman's, the VA worn-of-women, and the Cupid female condoms: a randomised controlled non-inferiority crossover trial. Lancet Glob Health. 2013;1(3):e146-52.

5. Mantell JE, Smit JA, Exner TM, Mabude Z, Hoffman S, Beksinska M, et al. Female condom use among Female University Students in KwaZuluNatal, South Africa: results of a randomized behavioural trial. AIDS Behav. 2015;19(7):1129-40

6. Masvawure TB, Mantell JE, Mabude Z, Ngoloyi C, Milford C, Beksinska M, et al. "It's a different condom, let's see how it works": young men's reactions to and experiences of female condom use during an intervention trial in South Africa. J Sex Res. 2014;51(8):841-51.
7. Mutowo J, Kasu CM, Mufunda E. Women empowerment and practices regarding use of dual protection among family planning clients in urban Zimbabwe. Pan Afr Med J. 2014;17:300.

8. Peters AJ, Van Driel FTM, Jansen WHM. Silencing women's sexuality: global AIDS policies and the case of the female condom. J Int AIDS Soc. 2013;16(18452):1-12.

9. Adebowale AS, Titiloye M, Fagbamigbe AF, Akinyemi OJ. Statistical modeling of social risk factors for sexually transmitted diseases among female youths in Nigeria. J Infect Dev Ctries. 2013;7(1):017-27.

10. Akinyemi JO, Awolude OA, Adewole IF, Kanki PJ. Condom use among antiretroviral therapy patients in Ibadan, Nigeria. J Infect Dev Ctries. 2010;4(8):495-502.

11. Adebowale SA, Ajiboye BV, Arulogun O. Patterns and correlates of condom use among unmarried male youths in Nigeria:NDHS 2008. Afr J Reprod Health. 2013;17(3):149-59.

12. Kavinya T. Opinions on the use of the female condoms by Malawian women. Malawi Med J. 2013;25(3):2013.

13. Adebiyi A, Asuzu M. Condom use amongst out of school youths in a local government area in Nigeria. Afr Heal Sci. 2009;9(2):92-7.

14. Okunlola MA, Moharson-Bello IO, Owonikoko KM, Adekunle AO. Female condom awareness, use and concerns among Nigerian female undergraduates. J Obstet Gynaecol. 2006;26(4):353-6.

15. Olaniran A, Persson L, Oyekanmi F. Factors influencing condom use among Nigeria Undergraduates: a mixed method study. East Afr Med J. 2012;89(12):399-407.

16. Green EC, Murphy E. Health Belief Model. Ltd: Wiley; 2014.

17. Joseph G, Burke NJ, Tuason N, Barker J, Pasick R. Pereived susceptibility to illness and perceived benefits of preventive care: an exploration of behavioural theory constructs in a transcultural context. Health Educ Behav. 2009;36(5 Supp(415)):S71-90.

18. Schwarzer R. Self-efficacy: thought control of action. Beijing: Taylor \& Francis; 2014.

19. Leung WC. How to design a questionnaire. Stud BMJ. 2001:9:171-216.

20. Farr JN, Jenkins JJ, Paterson DG. Simplification of flesh reading ease formula. J Appl Psychol. 1951;35:333-7.

21. Scott B. Readability formulas. Free text readability consensus calculator. My Byline Media. 2015. http://www.readabilityformulas.com/free-readability-formula-tests.php. Accessed 28 Jan 2016.

22. Baele J, Dusseldorp E, Maes S. Condom use self-efficacy: effect on intended and actual condom use in adolescents. J Adolesc Health. 2001;28(5):421-31.

23. Shaweno D, Tekletsadik E. Validation of the condom use self-efficacy scale in Ethiopia. BMC Int Health Hum Rights. 2013;13:22.

24. Mtayangulwa R, Kayombo E. Knowledge, attitude and use of female condoms among female undergraduate students in University of Dar-EsSalaam. J Sci Res Rep. 2016;9(2):1-10.

25. Morsanyi K, Handley SJ, Serpell S. Making heads or tails of probability: an experiment with random generators. Br J Educ Psychol. 2012;83(3):379-95.

26. Jimoh AAG, Agbede OO, Abdulraheem IS, Saka MJ, Abubakar D, Olarinoye $\mathrm{AO}$, et al. Antiretroviral treatment among students of Tertiary Institutions in Ilorin; assessment of knowledge, attitudes and practice. Niger Med Pract. 2008;53(6):91-8.

27. National Population Commission (NPC) [Nigeria] and ICF International. Nigeria Demographic and Health Survey 2013. Abuja Niger: NPC and ICF International; 2014.

28. Oyo. The Official Website of Oyo State. The Pacesetter State. 2014. http:// www.oyostate.gov.ng/about-oyo-state/. Accessed 12 Mar 2016.

29. Odeyemi K, Onajole A, Ogunowo B. Sexual behaviour and the influencing factors among out-of-school female adolescents in Mushin market, Lagos, Nigeria. Int J Adolesc Med Health. 2009;21(1):101-9.

30. Sweat MD, Denison J, Kennedy C, Tedrow V, O'Reilly K. Effects of condom social marketing on condom use in developing countries: a systematic review and meta-analysis, 1990-2010. Bull World Health Organ. 2012;90(8):613-622A

31. Mvundura M, Nundy N, Kilbourne-Brook M, Coffey PS. Estimating the hypothetical dual health impact and cost-effectiveness of the woman's condom in selected sub-Saharan African countries. Int J Womens Health. 2015;7:271-7. 
32. Iwuagwu SC, Ajuwon AJ, Olaseha IO. Sexual behaviour and negotiation of the male condom by female students of the University of Ibadan, Nigeria. J Obstet Gynaecol. 2000;20(5):507-13.

33. Ankomah A, Adebayo SB, Anyanti J, Ladipo O, Ekweremadu B. Determinants of condom use by men in extramarital relationships in Nigeria. HIV/ AIDS Res Palliat Care. 2013;5:97-109.

34. Ayoola OD, Victoria G-OC, Bamidele O, Olufela KO, Oluwatosin SE, Mbaneifo EP, et al. Pattern, challenges and correlates of condom use among Nigerians living with HIV infection. Asian Pac J Trop Biomed. 2014;4(Suppl 1):S198-203.

35. Slap GB, Lot L, Huang B, Daniyam CA, Zink TM, Succop PA. Sexual behaviour of adolescents in Nigeria: cross sectional survey of secondary school students. BMJ. 2003;326:15.

36. Adekanle DA, Isawumi Al. Late antenatal care booking and its predictors among pregnant women in South Western Nigeria. Online J Health Allied Sci. 2008;7(1):4

37. Holt K, Blanchard K, Chipato T, Nhemachena T, Blum M, Stratton L, et al. A nationally representative survey of healthcare provider counselling and provision of the female condom in South Africa and Zimbabwe. BMJ Open. 2013;3(3):1-8.

38. Terris-Prestholt F, Windmeijer F. How to sell a condom? The impact of demand creation tools on male and female condom sales in resource limited settings. J Health Econ. 2016;48:107-20.

39. Beksinska ME, Smit JA, Ross G, Maphumulo B V, Mphilli N, Chonco S. Acceptability and ease of use of new female condom designs among women attending an urban reproductive health clinic in Durban, South Africa. 2014.
40. Beksinska ME, Smit JA, Mantell JE. Progress and challenges to male and female condom use in South Africa. Sex Health. 2012;9(1):51-8.

41. Holden S. Failing women, withholding protection: 15 lost years in making the female condom accessible, vol. 115. Oxford: Oxfam; 2008.

42. Magar V. Gender, health and the sustainable development goals. Bull World Health Org. 2015;93:743.

43. Raiseler J, Cohn J. Mother, midwives, and HIV/AIDS in sub-Saharan Africa. J Midwifery Women's Health. 2005;50:275-82.

44. Weeks MR, Coman E, Hilario H, Li J, Abbott M. Initial and sustained female condom use among low-income urban US women. J Women's Health. 2013;22(1):26-36

45. WHO. Nigeria develops new National Health Policy to accommodate emerging trends. 2016. p. 1-7. http://www.afro.who.int/en/nigeria/pressmaterials/item/8750-nigeria-develops-new-national-health-policy-toaccommodate-emerging-trends.html. Accessed 8 Dec 2016.

46. Federal Ministry of Health. Revised National Health Policy. Abuja; 2004.

47. WHO. WHO Country Cooperation Strategy 2014-2019 Nigeria; 2014.

48. Vuylsteke B, Jana S. Reducing HIV Risk in sex workers, their clients and partners. HIV/AIDS prevention and care in resource-constrained settings: a handbook for the design and management of programs. 2001. p. 191-210.

49. Obembe TA. Perceived Confidence Female Condom. Figshare; 2016. https://figshare.com/articles/Preceived_Confidence_Female_Condom/4491650. Accessed 12 Dec 2016.

\section{Submit your next manuscript to BioMed Central and we will help you at every step:}

- We accept pre-submission inquiries

- Our selector tool helps you to find the most relevant journal

- We provide round the clock customer support

- Convenient online submission

- Thorough peer review

- Inclusion in PubMed and all major indexing services

- Maximum visibility for your research

Submit your manuscript at www.biomedcentral.com/submit 